\title{
Kalkvakaóhóf vegna
kkirtilsæxlis í brjóstholi - \\ Kalkvakaóhóf vegna
kalkkirtilsæxlis í brjóstholi - sjúkratilfelli með umfjöllun
}

\begin{abstract}
Hrund 72 ára karlmaður leitaði á bráðamóttöku vegna Pórhallsdóttir ${ }^{1}$ deildarlæknir

\section{Kristján Skúli Ásgeirsson ${ }^{1}$} skurðlæknir

Ágústa Ólafsdóttir ${ }^{2}$ lyflæknir

Tómas

Guðbjartsson ${ }^{1,3}$

\section{Ágrip}

dreifðra lið- og vöðvaverkja, preytu og minnis-

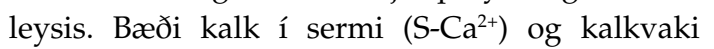
(S-PTH, serum parathyroid hormone) reyndust hækkuð en stækkaðir kalkkirtlar fundust ekki við ómskoðun af hálsi. Á kalkirtlaskanni sást hins vegar aukin upptaka í fremra miðmæti sem á tölvusneiðmynd reyndist vera 1,5 $\mathrm{cm}$ stór fyrirferð. Fyrirferðin var fjarlægð í gegnum bringubeinsskurð og reyndist góðkynja kalkkirtilsæxli (adenoma). Einkenni hurfu á nokkrum vikum. Tilfellið sýnir hversu fjölskrúðug einkenni geta fylgt frumkomnu kalkvakaóhófi og að orsök pess getur verið kalkkirtilsæxli staðsett í brjóstholi.
\end{abstract}

hjarta- og lungnaskurðlæknir

Lykilorð: kalkvakaóhóf, hækkað kalk í blóði, kalkirtlar, kalkirtlaæxli, góđkynja æxli, miðmæti.

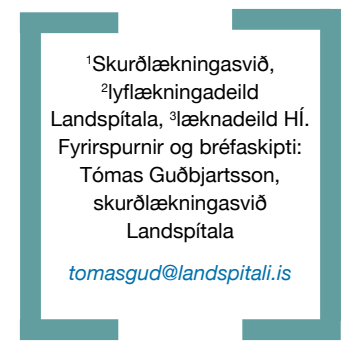

\section{Tilfelli}

Rúmlega sjötugur karlmaður leitaði á bráðamóttöku Landspítala eftir að hafa haft dreifða lið- og vöðvaverki í tvær vikur. Við komu kvartaði hann undan verkjum í mjóbaki, mjöðmum, öxlum, úlnliðum og fingrum beggja handa og átti erfitt með gang. Ættingjar höfðu jafnframt tekið eftir depurð, fannst hann gleyminn og ólíkur sjálfum sér. Hann hafði sögu um háprýsting en einnig vinstri helftarlömun fjórum árum áður sem að mestu hafði gengið til baka. Hann var á eftirtöldum lyfjum; valsartani, aspiríni og íbúprófen. Hann var hitalaus, gaf óljósa sögu og ekki fyllilega áttaður á stund. Annað markvert við skoðun var bjúgur á höndum og samhverf bólga í smáliðum fingra. Einnig var hreyfigeta skert í öxlum og mjöðmum. Blóðprufur sýndu vægt lækkaðan blóðrauða $123 \mathrm{mg} / \mathrm{L}$ (viðmiðunarmörk 134-171 mg/L) en að öðru leyti eðlilegan blóðhag. S-CRP (C reactive protein), var hækkað 140 mg/L (viðmiðunarmörk <6 mg/L), sökk mældist $53 \mathrm{~mm} / \mathrm{klst}$ (viðmiðunarmörk $<15$ $\mathrm{mm} /$ klst) og kreatínín var 79 umól/L. Vegna gruns um gigtarsjúkdóm voru mæld gigtarpróf og fengnar röntgenmyndir af liðum sem allar reyndust eðlilegar. Við frekari blóðrannsóknir kom í ljós hækkað jóniserað kalk (S-Ca $\left.{ }^{+2}\right)(1,53$ $\mathrm{mmol} / \mathrm{L}$, viðmiðunarmörk 1,13-1,33 mmol/L) og kalkvaki (S-PTH) (94 ng/L, viðmiðunarmörk 15-65 ng/L). Sólarhringsútskilnaður á kalki í pvagi var eðlilegur. Orsök kalkhækkunar samrýmdist pví frumkomnu kalkvakaóhófi. Við ómskoðun af hálsi var ekki hægt að sýna fram á stækkaða kalkkirtla, en kalkkirtlaskann $(99 \mathrm{~m}$ Tc-sestamibi) sýndi hins vegar aukna upptöku í fremri hluta miðmætis (mynd 1). Við frekari rannsóknir með tölvuneiðmyndum var sýnt fram á $1,5 \mathrm{~cm}$ fyrirferð í fremra miðmæti, nánar tiltekið við ósæðarbogann, um pað bil $7 \mathrm{~cm}$ frá efri kanti bringubeins (mynd 2).

Ákveðið var að gera skurðaðgerð, enda sjúklingur með töluverð einkenni. Byrjað var með hálsskurði en ekki tókst að ná til fyrirferðarinnar

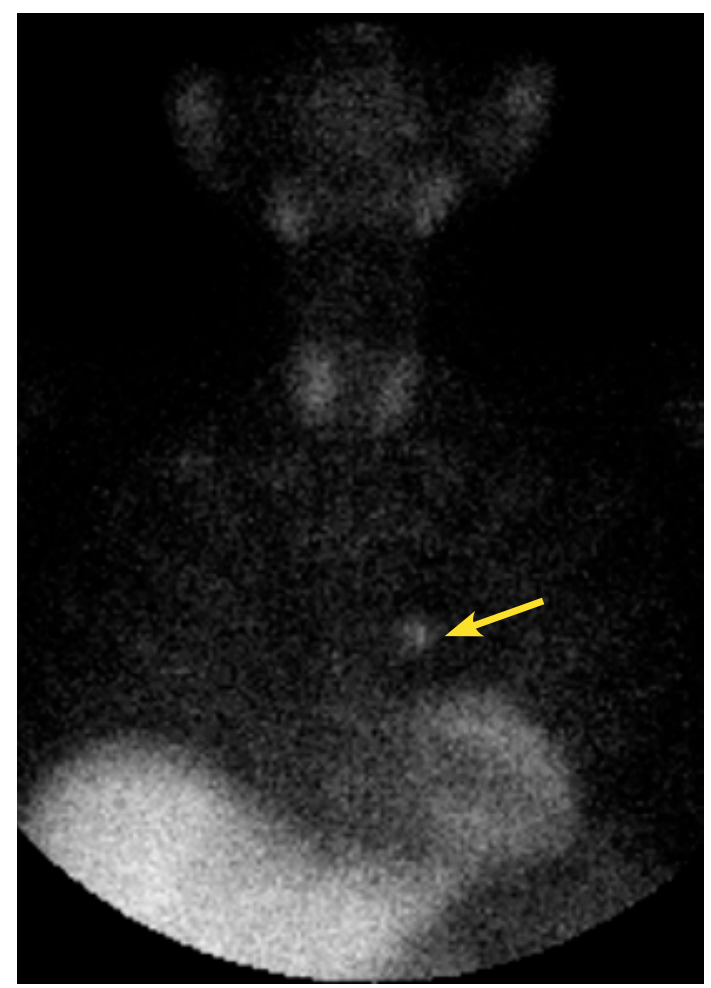

Mynd 1. Kalkirtlaskann (99m Tc-sestamibi) sem sýnir aukna upptöku í framanverðu miðmæti (ör). 
Mynd 2. Tölvusneiðmynd af brjóstholi (pversnið) sem sýnir 1,5 fyrirferd framanverðu miðmæti (ör), rétt neðan við ósæðarboga.

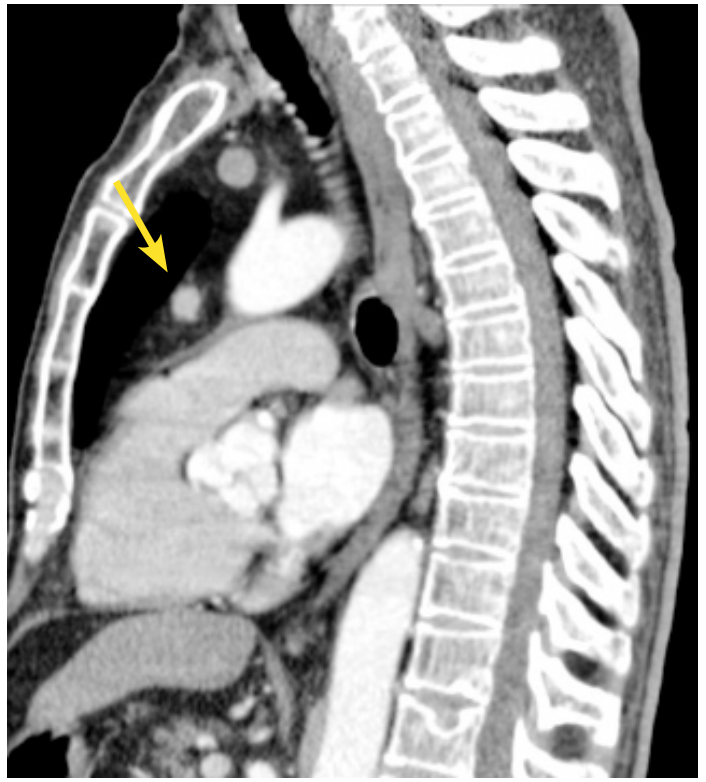

pannig. Pví var gerður efri bringubeinsskurður (partial sternotomy). Fyrirferðin sást pá greinilega í framanverðu miðmæti, vel afmörkuð frá umlykjandi fituvef (mynd 3). Frystiskurðarsvar í aðgerð gaf til kynna að líklegast væri um góðkynja kalkkirtilsæxli aðræða. Var greiningin síðar staðfest með smásjárskoðun á vefjasýnum (mynd 4). Gangur eftir aðgerð var góður og sjúklingurinn útskrifaðist tveimur dögum eftir aðgerð með eðlileg kalkgildi í blóði. Premur vikum frá aðgerð voru liðeinkenni horfin og vitsmunageta eðlileg. Sjúklingur er við góða líðan rúmu ári frá aðgerð og bæði kalk- og kalkvakagildi í sermi eðlileg.

\section{Umræður}

Einkenni sjúklingsins má rekja til blóðkalkshækkunar vegna frumkomins kalkvakaóhófs. Er pá um að ræða óeðlilega mikla seytrun á kalkvaka (parathyroid hormone), sem ásamt

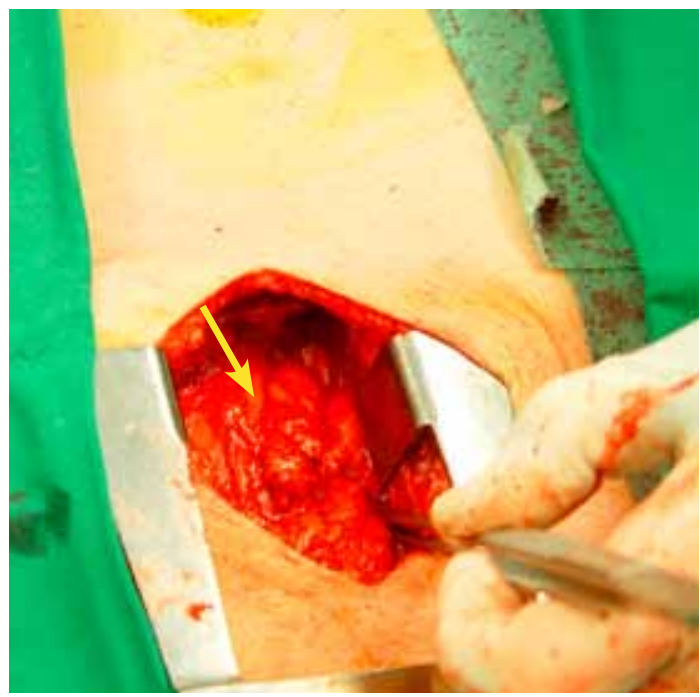

hormónunum kalsítónín og kalsítriol (1,25-(OH) cholecalciferol) stýra magni kalks í blóði. ${ }^{1}$ Tilfellið sýnir ágætlega hversu fjölbreytileg sjúkdómsmyndin getur verið, sem rekja má til víðtæks hlutverks kalks í líkamanum. Kalk er til dæmis nauðsynlegt fyrir boðskipti frumna, taugaboð, vöðvasamdrátt, storkun blóðs auk pess að vera eitt helsta byggingarefni beina. ${ }^{1,2}$ Engu að síður er frumkomið kalkvakaóhóf í dag oftar en ekki greint án einkenna, eða í allt að $80 \%$ tilfella. ${ }^{3}$ Er pá hækkun á kalki oftast greind í blóðprófum sem tekin eru við eftirlit vegna óskyldra sjúkdóma. ${ }^{4,5}$

Einkenni kalkvakaóhófs má rekja til hækkunar á kalki og kalkvaka í blóði. Einkenni nýrnasteina eru algengust og sjást hjá um 15-30\% sjúklinga. ${ }^{1,4}$ Í pessu tilfelli var pvagskoðun eðlileg og sjúklingur ekki með sögu um nýrnasteina. Kraftleysi og preyta voru hins vegar áberandi, en slík einkenni sjást hjá stórum hluta sjúklinga. ${ }^{3,6-8}$ Stirðleiki í liðum og jafnvel liðbólgur koma fyrir ${ }^{3}$ og eru pessir sjúklingar pví stundum taldir hafa gigtsjúkdóma. Beinpynning er pekktur fylgikvilli frumkominnar kalkvakaofseytingar og beinbrot sem afleiðing hennar. ${ }^{1,3,6}$ Geðræn einkenni eru vel pekkt, sérstaklega punglyndi og kvíði. ${ }^{3,10}$ Einnig hefur verið lýst geðrofa og ruglástandi, og eins og í pessu tilfelli skertri vitsmunagetu og gleymni. ${ }^{3,}$ ${ }^{10}$ Faraldsfræðilegar rannsóknir hafa sýnt fram á hærri dánartíðni af völdum hjarta- og æðasjúkdóma hjá sjúklingum með alvarlegt frumkomið kalkvakaóhóf. ${ }^{11}$ Ástæðan er ekki að fullu pekkt en frumkomið kalkvakaóhóf hefur verið tengt áhættupáttum fyrir hjarta- og æðasjúkdóma. Ber par helst að nefna háprýsting en einnig hefur í sumum rannsóknum verið sýnt fram á aukna tíðni skerts sykurpols og blóðfituraskana. ${ }^{11}$ Stækkun vinstri slegils er einnig algengari hjá pessum sjúklingum. ${ }^{12}$

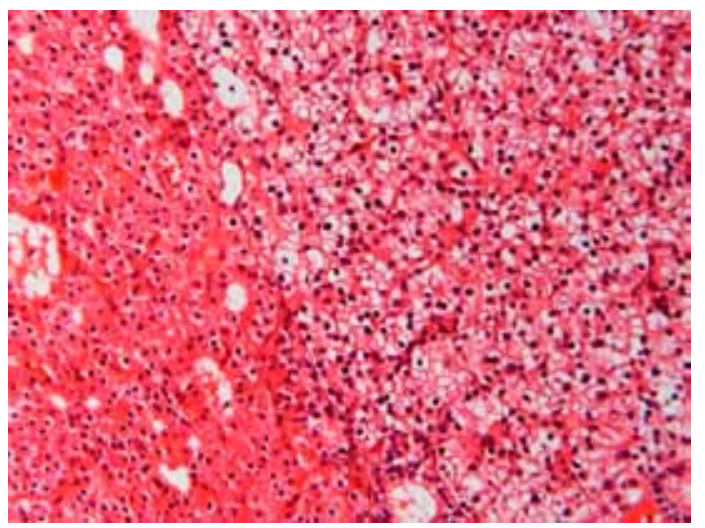

Mynd 4. Frumuríkur kalkkirtilsvefur sem er gerður af höfuðfrumum (chief cells) hægra megin á myndinni og sýrusæknum frumum (oxyphil cells) sem litast rauðar vinstra megin á myndinni. 
Kalkvaka er seytt af kalkkirtlum sem yfirleitt eru fjórir talsins og staðsettir pétt upp við skjaldkirtilinn aftanverðan. Magn kalkvaka eykst pegar kalk í blóði lækkar og hormónið hvetur beinátufrumur (oseteoclasta) til niðurbrots á beini sem losa pannig kalk út í blóðið. Einnig hvetur kalkvaki til endurupptöku á kalki í nýrum og meltingarvegi og hindrar endurupptöku fosfats í nýrum. ${ }^{1}$

Pegar kalkvakaóhóf er tilkomið vegna sjúkdóms í kirtlunum sjálfum kallast pað frumkomið kalkvakaóhóf (primary hyperparathyroidism). Hækkun á kalkvakagildum getur einnig sést sem afleiðing lækkunar kalks í blóði (secondary hyperparathyroidism), til dæmis við langvarandi nýrnabilun. Meðal annarra algengra orsaka er Dvítamín skortur. ${ }^{1}$

Árlegt nýgengi frumkomins kalkvakaóhófs er um 20-30/100 000 og sjúkdómurinn allt að fimm sinnum algengari hjá konum. ${ }^{13,14}$ Góðkynja æxli (adenoma) í einum kalkkirtli af fjórum er algengasta orsök frumkomins kalkvakaóhófs, eða hjá 80-88\% sjúklinga. ${ }^{15-17}$ Stundum eru góðkynja æxli í fleiri en einum kirtli, eða í 5-12\% tilfella, og 1 $5-15 \%$ tilfella er orsökin ofvöxtur (hyperplasia) í peim öllum. ${ }^{15-17}$ Mun sjaldgæfara er að krabbamein í kirtlunum valdi kalkvakaóhófi, eða í 1-2\% tilfella. Í okkar tilfelli reyndist einn kirtill stækkaður en staðsetning hans í miðju brjóstholi er óvenjuleg. Er talið að slík staðsetning sjáist í 5\% tilfella af frumkomnu kalkvakaóhófi. ${ }^{18}$ Annars eru $20 \%$ kalkkirtla staðsettir utan skjaldkirtilssvæðis, til dæmis í grófinni milli barka og vélinda, á bak við vélinda eða kok (retropharyngeal) eða í aftan- eða framanverðu miðmæti. ${ }^{19}$ Skýringuna á breytilegri staðsetningu kalkkirtla má rekja til fósturskeiðs. Líkt og hóstarkirtillinn myndast neðri kalkkirtlarnir frá priðja fósturboga í 5 . viku fósturskeiðs ${ }^{20}$ og ferðast peir saman umtalsverða vegalengd áður en endanleg staðsetning ræðst.

Hækkun kalks í blóði án bælingar kalkvakagildis (PTH) er oftast tilkomin vegna frumkomins kalkvakaóhófs. Mismunagreining er Familial Hypocalciuric Hypercalcemia (FHH), en með mælingu kalks í sólarhringspvagi eða útreikningum á

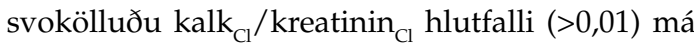
útiloka pann sjúkdóm. Frekari rannsóknir miða að pví að staðsetja kalkkirtilsæxlið og er oftast gerð bæði ómskoðun (næmi 42-82\% og sértæki 90$92 \%)^{21}$ og kalkkirtlaskann (allt að 90\% næmi pegar um eitt æxli er að ræða). ${ }^{21,22}$ Ef kalkkirtlaskann sýnir grun um æxli í brjóstholi er ennfremur mælt með tölvusneiðmynd eða segulómskoðun. Pannig fást nákvæmari upplýsingar um staðsetningu ${ }^{23}$ og var slíkt gert í pessu tilfelli.
Tafla I. Ábendingar fyrir skurðaðgerð hjá sjúklingum með kalkvakaóhóf. Byggt er á leiðbeiningum frá National Institutes of Health (1992 og 2002). ${ }^{26}$

Einkenni frá beinum, nýrum, meltingarfærum, vöðva- og taugakerfi eða lífshættuleg einkenn kalkhækkunar í blóði.

Kalkmagn í blóði >0,25 mmól/L ofan við efri viðmiðunarmörk.

Kalkmagn í pvagi >100 mmól/L eđa nýrnasteinar til staðar

Lág beinpéttni (T-gildi <-2,5)

Nýrnaskiljupróf (creatine clearance) $<30 \%$

Aldur $<50$ ár

Sjúklingur óskar sjálfur eftir aðgerð, litlar líkur á að sjúklingur sinni eftirliti.

Meðferð kalkvakaóhófs er skurðaðgerð par sem kirtilæxlið er fjarlægt, oftast í gegnum hálsskurð. ${ }^{25-26}$ Nær undantekningarlaust er mælt með aðgerð ef sjúklingar hafa einkenni sjúkdómsins, eins og í pessu tilfelli. Í mörgum tilvikum er einnig mælt með aðgerð hjá einkennalausum sjúklingum. Á pað til dæmis við hjá einstaklingum með beinpynningu, versnandi nýrnastarfsemi eða blóðkalkshækkun >0,25 mmól/1 yfir efri viðmiðunarmörkum. ${ }^{11,}{ }^{24}$ Í töflu I eru sýndar helstu ábendingar skurðaðgerðar.6, 24 Árangur aðgerðar er mjög góður og tíðni fylgikvilla lág (2-3\%), ${ }^{26}$ sérstaklega ef hún er framkvæmd af reyndum skurðlækni. Má gera ráð fyrir að 98\% sjúklinga læknist með skurðaðgerð ${ }^{23}$ eins og sást í pessu tilfelli. Í aðgerðinni er hægt að staðfesta að um kalkkirtil sé að ræða með frystiskurði eða stundum PTH-mælingu í aðgerð. Helstu fylgikvillar eru tímabundin lækkun á kalki í blóði, hæsi vegna áverka á raddbandataugar ( $n$. laryngeus recurrence) og blæðing í kjölfar aðgerðar. ${ }^{26}$ Í um $2 \%$ tilfella er pörf á bringubeinsskurði til að fjarlægja pessi æxli. ${ }^{27}$ Par sem fylgikvillar og legutími eru hærri eftir bringubeinsskurð, er yfirleitt reynt að ná til æxlisins í gegnum hálsskurð, sé pað mögulegt. Er pá stundum miðað við að æxlið liggi ekki dýpra en $6 \mathrm{~cm}$ frá bringubeinskantinum. ${ }^{28}$ Í pessu tilfelli var reynt að ná til æxlisins í gegnum hálsskurð en ekki náðist í æxlið og var pví gerður efri bringubeinsskurður.

Tilfellið sýnir að einkenni frumkomins kalkvakaóhófs geta verið margvísleg og sjúkdómsmyndin óljós. Kalkkirtilsæxli geta fundist utan hálssvæðis, meðal annars í brjóstholi eins og hér er lýst. Frumkomið kalkvakaóhóf er hægt að lækna með skurðaðgerð en sjaldgæft er að grípa purfi til bringubeinsskurðar til að fjarlægja æxlið eins og í pessu tilfelli.

\section{Pakkir}

Pakkir fá læknarnir Vigdís Pétursdóttir meinafræðingur og Maríanna Garðarsdóttir röntgenlæknir fyrir aðstoð við gerð myndefnis. 


\section{Heimildir}

1. Fraser WD. Hyperparathyroidism. Lancet 2009; 374: 145-58.

2. Tfelt-Hansen J, Brown EM. The calcium-sensing receptor in normal physiology and pathophysiology: a review. Crit Rev Clin Lab Sci 2005; 42: 35-70.

3. Chan AK, Duh QY, Katz MH, Siperstein AE, Clark OH Clinical manifestations of primary hyperparathyroidism before and after parathyroidectomy. A case-control study. Ann Surg 1995; 222: 402-12.

4. Silverberg SJ, Bilezikian JP. Evaluation and management of primary hyperparathyroidism. J Clin Endocrinol Metab 1996; 81: 2036-40

5. Eigelberger MS, Cheah WK, Ituarte PH, Streja L, Duh QY, Clark $\mathrm{OH}$. The $\mathrm{NIH}$ criteria for parathyroidectomy in asymptomatic primary hyperparathyroidism: are they too limited? Ann Surg 2004;239: 528-35.

6. Mazzaglia PJ, Berber E, Kovach A, Milas M, Esselstyn $C$, Siperstein AE. The changing presentation of hyperparathyroidism over 3 decades. Arch Surg 2008; 143 260-6.

7. Lundgren E, Ljunghall S, Akerstrom G, Hetta J, Mallmin $\mathrm{H}$, Rastad J. Case-control study on symptoms and signs of "asymptomatic" primary hyperparathyroidism. Surgery 1998; 124: 980-5.

8. Mallette LE, Bilezikian JP, Heath DA, Aurbach GD. Primary hyperparathyroidism: clinical and biochemical features Medicine (Baltimore) 1974; 53: 127-46.

9. McAllion SJ, Paterson CR. Psychiatric morbidity in primary hyperparathyroidism. Postgrad Med J 1989; 65: 628-31.

10. Coker LH, Rorie K, Cantley L, et al. Primary hyperparathyroidism, cognition, and health-related quality of life. Ann Surg 2005; 242: 642-50.

11. Wermers RA, Khosla S, Atkinson EJ, et al. Survival after the diagnosis of hyperparathyroidism: a population-based study. Am J Med 1998; 104: 115-22.

12. Almqvist EG, Bondeson AG, Bondeson L, Nissborg A, Smedgard P, Svensson SE. Cardiac dysfunction in mild primary hyperparathyroidism assessed by radionuclide angiography and echocardiography before and after parathyroidectomy. Surgery 2002; 132: 1126-32.

13. Sitges-Serra A, Bergenfelz A. Clinical update: sporadic primary hyperparathyroidism. Lancet 2007; 370:468-70.

14. Wermers RA, Khosla S, Atkinson EJ, et al. Incidence of primary hyperparathyroidism in Rochester, Minnesota 1993-2001: an update on the changing epidemiology of the disease. J Bone Miner Res 2006; 21: 171-7.

15. Salti GI, Fedorak I, Yashiro T, et al. Continuing evolution in the operative management of primary hyperparathyroidism Arch Surg 1992; 127: 831-6.
16. Szabo $E$, Lundgren $E$, Juhlin $C$, Ljunghall $S$, Akerstrom G, Rastad J. Double parathyroid adenoma, a clinically nondistinct entity of primary hyperparathyroidism. World J Surg 1998; 22:708-13

17. Ruda JM, Hollenbeak CS, Stack BC, Jr. A systematic review of the diagnosis and treatment of primary hyperparathyroidism from 1995 to 2003. Otolaryngol Head Neck Surg 2005; 132: 359-72.

18. Phitayakorn R, McHenry CR. Incidence and location of ectopic abnormal parathyroid glands. Am J Surg 2006; 191: $418-23$

19. Thompson NW, Eckhauser FE, Harness JK. The anatomy of primary hyperparathyroidism. Surgery 1982; 92: 814-21.

20 Lew JI, Solorzano CC. Surgical management of primary hyperparathyroidism: state of the art. Surg Clin North Am 2009; 89: 1205-25.

21. Udelsman R, Pasieka JL, Sturgeon C, Young JE, Clark OH. Surgery for asymptomatic primary hyperparathyroidism: proceedings of the third international workshop. J Clin Endocrinol Metab 2009; 94: 366-72

22. Civelek AC, Ozalp E, Donovan P, Udelsman R. Prospective evaluation of delayed technetium-99m sestamibi SPECT scintigraphy for preoperative localization of primary hyperparathyroidism. Surgery 2002; 131: 149-57.

23. Udelsman R. Six hundred fifty-six consecutive explorations for primary hyperparathyroidism. Ann Surg 2002; 235: 66570

24. Caron NR, Pasieka JL. What symptom improvement can be expected after operation for primary hyperparathyroidism? World J Surg 2009; 33: 2244-55.

25. Grant CS, Thompson G, Farley D, van Heerden J. Primary hyperparathyroidism surgical management since the introduction of minimally invasive parathyroidectomy: Mayo Clinic experience. Arch Surg 2005; 140: 472-8.

26. Allendorf J, DiGorgi M, Spanknebel K, Inabnet W, Chabot J, Logerfo P. 1112 consecutive bilateral neck explorations for primary hyperparathyroidism. World J Surg 2007; 31: 207580 .

27. Lunca S, Stanescu C, Bouras G, Vix M, Marescaux J. A difficult case of mediastinal parathyroid adenoma: theoretical and clinical considerations. Chirurgia (Bucur) 2004; 99: 563-6.

28. Callender GG, Grubbs, Vu T, Hofstetter WL, et al. The fallen one: the inferior parathyroid gland that descends into the mediastinum. J Am Coll Surg 2009; 208: 887-95.

\section{Primary hyperparathyroidism due to an intrathoracic parathyroid adenoma. - A case report and review of the literature}

A 72 year old gentleman presented to the emergency department with symptoms of diffuse joint and muscular pain, fatigue and diminished memory. Serum calcium and parathyroid hormone levels were raised, consistent with primary hyperparathyroidism. No abnormality was found on an ultrasound scan of the neck. However, a sestamibi scan suggested a possible adenoma in the anterior mediastinum, which on computed tomography

Thorhallsdottir H, Asgeirsson KS, Gudbjartsson T.

Primary hyperparathyroidism due to an intrathoracic parathyroid adenoma. - A case

report and review of the literature. Icel Med J 2010; 96: 469-72.

Key words: Primary hyperparathyroidism, hypercalcemia, parathyroid adenoma

mediastinum, surgery, case report.

Correspondence: Tómas Guðbjartsson, tomasgud@landspitali.is
(CT) scan was $1.5 \mathrm{~cm}$ in size. A partial upper sternotomy was performed in order to excise the adenoma and his symptoms disappeared within several weeks. This case highlights the variable and commonly nonspecific symptoms of primary hyperparathyroidism and the less well known fact that parathyroid adenoma may occasionally be found intrathoracically.

Barst: 30. nóvember 2009, - sampykkt til birtingar: 1. maí 2010 Hagsmunatengsl: Engin 